\title{
TERMINOLOGIAS EM (TRANS)FORMAÇÃO EM LINGUÍSTICA APLICADA: UMA REFLEXÃO À LUZ DO PARADIGMA DA COMPLEXIDADE
}

\section{TERMINOLOGY IN (TRANS)FORMATION IN APPLIED LINGUISTICS: A REFLECTION THROUGH THE LENSES OF THE COMPLEXITY PARADIGM}

Cláudia Almeida Rodrigues Murta ${ }^{166}$

Valeska Virgínia Soares Souza ${ }^{167}$

Valéria Lopes de Aguiar Bacalán ${ }^{168}$

RESUMO: Neste ensaio, inserido na seara da Linguística Aplicada (LA), buscamos subsídios na Terminologia e no Paradigma da Complexidade para analisar diversos termos utilizados para se referir às línguas que náo sejam a materna. Primeiramente, apresentamos um breve histórico das áreas da Terminologia e da LA no Brasil, apontando para a dinamicidade da marcaçăo terminológica que envolve as denominaçôes no que se refere à aprendizagem de línguas. Discorremos sobre conceitos da Teoria dos Sistemas Complexos que nos ajudam a esclarecer termos da LA e explicitamos como a língua pode ser considerada um sistema adaptativo complexo e a inserçăo da Terminologia nesse sistema. Posteriormente, analisamos alguns termos demonstrando como o Paradigma da Complexidade pode contribuir para o entendimento da fluidez do sistema de aprendizagem de línguas e como as terminologias devem traduzir tal complexidade.

Palavras-chave: Terminologia. Linguística Aplicada. Complexidade.

ABSTRACT: In this essay, inserted in the area of Applied Linguistics (AL), we have sought subsidy in Terminology and the Complexity Paradigm to analyze several terms used to refer to languages other than the mother tongue. First, we present a brief history of the areas of Terminology and AL in Brazil, pointing to the dynamics of terminological marking involving denominations related to language learning. We discuss concepts

166 Professora do Centro de Educaçăo Profissional (CEFORES) da Universidade Federal do TriânguloMineiro (UFTM). Doutoranda em Estudos Linguísticos pela Universidade Fedral de Uberlândia. E-mail: claudiarodriguesmurta@gmail.com.

167 Professora do Instituto Federal do Triângulo Mineiro. Doutora em Estudos Linguísticos pela Universidade Federal de Minas Gerais. E-mail: valeskasouza@iftm.edu.br.

168 Doutoranda na Universidade Federal de Uberlândia. E-mail: valeriabacala@gmail.com. 
of the Theory of Complex Systems that help to clarify the terms of AL and make explicit how language can be considered a complex adaptive system and the insertion of Terminology in this system. Subsequently, we analyze some terms demonstrating how the Paradigm of Complexity can contribute to understanding the fluidity of the language learning system and how terminologies should translate such complexity.

Keywords: Terminology. Applied Linguistics. Complexity.

\section{INTRODUÇÃO}

O momento histórico que vivemos demanda cada vez mais o entendimento de problemas de ordem sociocultural e linguística. Como processo e produto das relaçôes humanas, nesse contexto, a linguagem se constitui como objeto de investigaçâo das ciências sociais em geral e em especial na Linguística Aplicada (LA), que se preocupa com o uso da linguagem em diferentes contextos.

ALA, que por algum tempo esteve ligada à sua ciência măe, a Linguística, e sendo definida como a aplicaçăo dos estudos linguísticos ao ensino e aprendizagem de línguas estrangeiras, apresenta-se, na atualidade, como uma promissora área de investigaçăo em funçăo de seu caráter interdisciplinar, transdisciplinar e, segundo palavras de Moita Lopes (2006), (in)disciplinar. Isso significa que a LA nâo trabalha com limites rígidos, ela se constitui híbrida e heterogênea, com foco em outras áreas do conhecimento socialmente construído e utiliza diferenciados modos de analisá-los e que, inclusive, transgridem radicalmente os limites disciplinares.

A relaçăo entre teoria e prática na LA se apresenta no sentido de propor soluçóes para questôes que estâo além do que é somente linguístico, porque disciplinas como a psicologia, etnografia, antropologia, sociologia, pesquisa educacional, comunicaçăo e mídias adentram suas fronteiras. À LA interessa pesquisar sobre as questôes de bilinguismo e multilinguismo, da análise do discurso, da traduçăo, da política e planificaçâo da linguagem, da metodologia de pesquisa, da avaliaçăo, de estilística, de literatura, de retórica, de letramento, de problemas de ordem forense e de saúde e outras áreas em que decisóes relacionadas com a linguagem precisam ser tomadas (HOUSE, s.d.).

Apesar de as obras que discorrem sobre as diferentes áreas que a LA abrange (DAVIES; ELDER, 2004; HALL; SMITH; WICKASONO, 2011) se refiram à lexicografia e nâo à terminologia no que tange à construçăo de dicionários técnicos e profissionais, acreditamos que a terminologia apresenta linha epistemológica mais apropriada para o tratamento de termos em contextos de especialidade. Segundo Cabré (2003), a teoria terminológica vem ganhando espaço com novas propostas alternativas à teoria tradicional de Wüster (1937 apud CANO, 2001) após anos de inatividade.

Todo campo disciplinar demanda a delimitaçâo de um objeto, com suas metodologias e terminologias pertinentes ao campo de estudos a que se dedica, no sentido de se fazer reconhecido diante de outras ciências. Além disso, faz-se necessária a documentaçăo dos achados relevantes à humanidade, incluindo o seu histórico e isso năo tem sido diferente, em relaçăo à LA. Contudo, ao pensarmos no mundo em (trans) 
formaçăo ${ }^{169}$ em que vivemos, cujas fronteiras sâo tênues, que desconstrói conceitos, com tecnologias digitais sendo aperfeiçoadas, cada dia mais, é importante refletir sobre os marcos científicos que consolidam uma ciência, e que săo influenciados pelas condiçôes sócio-históricas às quais estăo vinculados.

Nessa condiçâo de dinamicidade, o Paradigma da Complexidade, propóe lentes que podem ser utilizadas para investigaçâo da plurireferencialidade terminológica atual. O Paradigma da Complexidade preocupa-se com o comportamento dos sistemas adaptativos complexos, ou seja, aqueles sistemas que sâo dinâmicos e que mudam com o tempo, e propóe uma visăo considera de forma indissociável as partes e o todo desses sistemas. Um dos pesquisadores dos sistemas adaptativos complexos, Holland (1995) discorre sobre um dos mecanismos desses sistemas que nos interessa: a marcaçăo. As marcas embasam a organizaçăo hierárquica e delimitam as fronteiras nos sistemas complexos. A marcaçăo facilita a interaçăo, pois torna os agentes distinguíveis. Na LA, as marcas de identidade, ou seja, as denominaçōes, se apresentam na contemporaneidade como dinâmicas, críticas, com a possibilidade de romper fronteiras epistemológicas e construir fundaçōes teóricas e empíricas que investigam e propōem possíveis soluçôes para os problemas relacionados à linguagem do mundo real (DAVIES, s.d.).

Nesse cenário de fluxo intenso de informaçôes, de comunicaçăo entre pessoas e de variada diversidade de línguas, indagamos sobre que termo usar para denominar uma língua em aprendizagem que náo a língua materna (LM) ou língua primeira (L1): língua estrangeira (LE), segunda língua (SL), língua nâo materna, língua adicional, língua de herança, língua de contato, língua-alvo, língua de acolhimento?

Esse ensaio tem como objetivo analisar e refletir sobre a terminologia que apresentamos acima e que está sendo utilizada pela LA no que se refere ao ensino e aprendizagem de línguas, à luz do Paradigma da Complexidade. Buscamos subsídios no Paradigma da Complexidade para entender o imbricamento de relaçóes entre as situaçôes de aprendizagem e funçōes que as línguas desempenham no contexto atual. Esse imbricamento influencia a conceptualizaçâo e, consequentemente, sua denominaçăo como marcaçăo de tais situaçôes e por isso problematizamos o uso dos termos relativos ao ensino e aprendizagem de línguas para que professores e pesquisadores possam pensar na relatividade de tais denominaçōes.

$\mathrm{O}$ que nos levou a desenvolver esse trabalho foi justamente pensar sobre um desses marcos científicos, a terminologia que a LA adotou, e a qual utiliza em seu campo de estudos, com a intençăo de problematizá-la no âmbito de ensino e aprendizagem de línguas.

Trabalhos de natureza terminológica sâo escassos no Brasil, especialmente em LA. $O$ único trabalho amplamente divulgado e publicado até o momento em nosso país é - Glossário de Linguística Aplicada organizado pelos professores José Carlos Paes de Almeida Filho e John Robert Schmitz (ALMEIDA FILHO; SCHMITZ, 1998), com a colaboraçấo de alunos de graduaçâo e pós-graduaçaâo, bem como de professores de línguas e alguns profissionais do domínio da formaçâo continuada na disciplina, Abordagens de Ensino de Línguas, do Programa de Pós-Graduaçâo em Linguística Aplicada da UnB, ofertada no segundo semestre de 2008. A obra abarca um repertório de aproximadamente

169 Optamos pela nâo-lexicalizaçăo de 'transformaçăo' e sim por sua segmentaçăo morfológica no intuito de marcar nossa concepçâo epistemológica de que o mundo se modifica contínua e dinamicamente. 
3.500 palavras, expressōes e siglas em Português e seus respectivos equivalentes em Inglês. A oferta de disciplinas posteriores no referido programa gerou listas de termos que compuseram novos verbetes para o Projeto Glossário Eletrônico de Linguística Aplicada ${ }^{170}$ (GLOSSALA).

Em língua inglesa, há um número maior de dicionários terminológicos disponíveis como: Encyclopedic Dictionary of Applied Linguistics: A Handbook for Language Teaching (JOHNSON; JOHNSON, 1998); Longman Dictionary of Language Teaching and Applied Linguistics (RICHARDS; SCHMIDT, 1985); A glossary of applied linguistics (DAVIES, 2005); Blackwell Reference Online; ${ }^{171}$ para citar alguns.

Iniciamos o desenvolvimento de nosso raciocínio fazendo um breve histórico da Terminologia e da Linguística Aplicada no Brasil com a recente evoluçáo e com a falta de sistematizaçâo terminológica e em seguida discorremos sobre os conceitos do Paradigma da Complexidade que mobilizamos para entender a necessidade de terminologias mais abrangentes e flexíveis para abarcar a gama de situaçóes de aprendizagem de línguas na atualidade. Finalizamos nossas elucubraçôes refletindo sobre as contribuiçóes do Paradigma da Complexidade para o entendimento da fluidez do sistema de aprendizagem de línguas e como as terminologias devem traduzir tal complexidade.

\section{A TERMINOLOGIA E A LINGUÍSTICA APLICADA NO BRASIL}

Antes de iniciarmos a discussăo sobre os caminhos da Linguística Aplicada no Brasil e sua relaçăo com a pesquisa em Terminologia, vale a pena traçarmos genericamente um percurso histórico tanto dos estudos terminológicos quanto do início dos estudos em LA.

A prática terminológica é antiga. A necessidade de sistematizar descobertas científicas e tecnológicas e reunir em vocabulários ou glossários a linguagem especializada utilizada nessas áreas do conhecimento remonta à Idade Média. Mas somente com o desenvolvimento dos estudos da linguagem e a constituiçấo da Linguística como ciência autônoma no século XX, que a sistematizaçăo dos termos ganhou uma área dentro dos estudos linguísticos. Desde entăo, inúmeros esforços têm sido empreendidos com o intuito de criar fundamentos teórico-metodológicos que sirvam de base para a criaçâo, coleta, descriçấo, processamento e apresentaçăo de termos de uma dada área de especialidade de uma ou mais línguas. Ao estudo científico destas unidades lexicais especializadas dá-se o nome de Terminologia (CABRÉ, 1993).

As bases científicas dos estudos terminológicos foram apresentadas em 1931, por Eugene Wüster, na Universidade de Viena, com sua tese intitulada de Internationale Sprashnormung in der Tecknik, besonders in der Elektrtechni (Normalizaçăo internacional da terminologia técnica). Esse estudioso foi responsável por criar a Teoria Geral da Terminologia (TGT). A TGT, apesar de sofrer críticas devido à sua natureza prescritiva e normalizadora, contribuiu para a consolidaçấo e o desenvolvimento da disciplina. A proposta da Teoria Geral da Terminologia concentra-se no conceito e nas

170 Disponível em: http://glossario.sala.org.br.

171 Disponível em: 〈http://www.blackwellreference.com/public/>. 
relaçôes conceituais, visando chegar às denominaçóes dos conceitos estabelecidos, livres da polissemia e ambiguidades da língua geral. Essa prescriçâo fez algum sentido em contextos rigidamente estruturados como as ciências exatas e no paradigma positivista. Entretanto, em situaçóes de comunicaçăo natural, de base social, especialmente aquelas encontradas nas ciências humanas, a TGT năo consegue dar conta dos processos envolvidos. Com a consolidaçâo das ciências humanas, os fatores socioculturais passam a ser preponderantes na análise científica e a metodologia positiva torna-se ineficaz nesse tipo de análise (CANO, 2001).

Critica-se a TGT devido ao postulado de que o conhecimento científico, em contraste com o conhecimento geral, preexiste a qualquer expressăo e é independente da bagagem cultural e linguística dos usuários; por acreditar que os termos ficariam restritos à comunicaçăo profissional, e, consequentemente, năo levar em conta os aspectos semânticos e comunicativos dos mesmos, ou seja, negar a variaçâo semântica e a evoluçăo dos conceitos; por nâo considerar as unidades terminológicas pertencentes à linguagem natural (CANO, 2001); e por nâo admitir a sinonímia como um fenômeno inerente ao processo de estruturaçăo do discurso especializado.

Os termos, ao contrário de como estabelecia Wüster (1937 apud CABRÉ, 1993), năo săo entidades supra-linguísticas, ou seja, năo ficam restritos ao universo especializado. Eles fazem parte da língua geral, adquirem o caráter de termo quando sâo usados em um discurso especializado, numa determinada situação comunicativa.

Para estabelecer um novo paradigma para os estudos terminológicos, Cabré (1999) menciona que é preciso esclarecer alguns pontos, tais como: a delimitaçáo do objeto, as perspectivas de análise do objeto, as funçôes que exercem a terminologia no discurso especializado, e o âmbito ou campo disciplinar em que se situa. E afirma

intenta compatibilizar a possibilidade de centrar o estudo da Terminologia em unidades homogêneas e abordáveis, de base linguística com a viabilidade de ir mais além de seus aspectos linguísticos para dar conta da complexidade das unidades terminológicas, complexidade que, por outro lado, poderiam reclamar todas as unidades da língua natural (CABRÉ 1999, p. 83).

Com a afirmaçăo exposta acima, Cabré assegura o caráter de poliedricidade do termo e também do signo linguístico como um todo. Nas palavras de Rondeau (apud CABRÉ, 1999, p. 88)

podemos dizer que textualmentea comunicaçăogeralea especializadacompartilham o mesmo território e utilizam as mesmas regras e processos linguísticos e textuais, e que o único que as faz variar é a seleçăo de unidades e a frequência com que cada recurso é atualizado no discurso. ${ }^{172}$

O modelo de estudo dos termos proposto por Cabré (1999), conhecido como escola Catalá de Terminologia, ou Teoria Comunicativa da Terminologia, se sustenta a partir de uma teoria lexical forte que contempla o componente léxico em um modelo de gramática que inclui, além de dados gramaticais, informaçōes pragmáticas e enciclopédicas sobre as unidades da gramática. Além disso, possui um mecanismo que dá conta da seleçăo de traços que realiza o falante numa situaçăo determinada.

172 Essa e demais traduções são de nossa responsabilidade. 
Uma revisăo dos pressupostos norteadores da Terminologia, valorizando os aspectos comunicativos das linguagens especializadas em detrimento de um sistema denominativo das ciências e tecnologias, impôe-se como uma necessidade, dado o avanço tecnológico do mundo atual e o alargamento do conceito de ciência. Em decorrência do surgimento das ciências humanas, que se estabeleceram com objeto, metodologias e terminologias próprias, nasceram termos com uma flexibilidade e transitividade muito relativas sendo preciso que os estudos terminológicos avançassem para atender às necessidades epistemológicas de tais ciências. O desenvolvimento dos estudos terminológicos acompanhou a evoluçăo dos estudos linguísticos e das ciências humanas em geral e elaborou teorias e metodologias mais alinhadas às transformaçōes socioculturais passando a levar em consideraçăo a disseminaçăo do conhecimento via tecnologias da informaçăo e comunicaçấo e a complexidade da linguagem, que nâo estabelece fronteiras nítidas entre o discurso geral e o especializado, como imaginavam os primeiros estudiosos da Terminologia Clássica.

Após discorrer sobre os caminhos da Terminologia, é importante também traçarmos um percurso histórico da Linguística Aplicada antes de discutirmos a relaçâo entre Terminologia e a Linguística Aplicada foco de nosso ensaio.

A Linguística Aplicada conta com uma tradiçâo histórica que remonta à década de 40, quando as primeiras tentativas de aplicar teorias ao ensino de língua inglesa foram desenvolvidas por Charles Fries e Robert Lado nos Estados Unidos, onde criaram o English Language Institute na Universidade de Michigan (MENEZES; SILVA; GOMES, 2009). Naquele momento de guerra, havia a necessidade de ensino de línguas para os soldados para que esses pudessem se comunicar com aliados ou inimigos. Portanto, o ensino de línguas aliado às teorias linguísticas foi uma questâo estratégica. Naquele momento, o cientificismo positivista imperava nas pesquisas e as bases da LA se constituíram nesse modelo de ciência, ou seja, como aplicaçâo de teorias linguísticas (estruturalistas a princípio) ao ensino.

Em 1956, foi criada a Escola de Linguística Aplicada na Universidade de Edimburgo para consolidar os estudos em LA na Europa. E mais tarde em 1964, o grande marco sistemático da Linguística Aplicada foi a fundaçăo da Association Internationel de Linguistique Apliquée (AILA) na cidade de Nancy na França. Em 1966, a British Association of Applied Linguistic, e em 1977 a American Association of Applied Linguistic. A expansāo da LA foi registrada pelos extensivos trabalhos publicados ao longo dos dez primeiros anos do Journal of Applied Linguistics e do Annual Review of Applied Linguistics (ARAL), fundado posteriormente, em 1980. Segundo Grabe (2002), o foco central da LA nesse período estava relacionado a acessar questóes e problemas de linguagem à medida que eles ocorriam no mundo real.

A AILA tem nos dias atuais milhares de associados no mundo todo e a cada três anos realiza um congresso internacional em localidades diferentes, sendo o maior evento em LA que reúne pesquisadores dos mais diferentes países com o intuito de discutir questóes relativas ao uso da linguagem e a prática social. Desde entâo, vem crescendo a adesấo de membros a essas associaçôes e os linguistas aplicados em todo o mundo.

No Brasil, segundo Menezes; Silva e Gomes (2009), os marcos históricos de ascensâo da LA foram a criaçấo de programas de pós-graduaçăo e áreas de concentraçấo em universidades brasileiras nas décadas de 70 e 80, situadas no estado de Săo 
Paulo. É fundado, na PUC-SP, o primeiro programa de Pós-Graduaçāo stricto-sensu em Linguística Aplicada. Em 1971, o Programa de Estudos Pós-Graduados em Linguística Aplicada ao Ensino de Línguas (LAEL) é reconhecido como centro de excelência pelo CNPq, e em 1973, o mesmo é credenciado pelo Conselho Federal de Educaçăo.

Outro marco lembrado pelos autores supracitados foi a criaçăo da ALAB (Associaçăo de Linguística Aplicada do Brasil) em 1990. De acordo com Rojo (1999), na década de 90, a diversificaçâo de enfoques, temas, objetos decorrente de teorias, descriçóes e metodologias, contribuiu para se colocar a discussáo da identidade da área de LA como um todo e para se aprofundar as discussóes sobre o seu caráter inter e/ou transdisciplinar. O foco das pesquisas do linguista aplicado passou a ser a presença de problemas com relevância social suficiente para exigir respostas teóricas que trouxessem benefícios sociais a seus participantes. Como ressalta Pennycook (1998), tornou-se importante compreender o sujeito como múltiplo, contraditório e construído dentro dos diferentes discursos. Os linguistas aplicados passaram a ter a necessidade de olhar as relaçóes de poder na formaçăo do sujeito na linguagem e por meio dela. Qualquer produçăo de conhecimento gerada em LA deve, portanto, responsabilizar-se por um projeto político que busque transformar uma sociedade desigualmente estruturada. Moita Lopes (1996) sintetiza explicando que a LA passou a ser uma área de investigaçâo aplicada, mediadora, centrada na resoluçăo de problemas de uso da linguagem, que tinha um foco na linguagem de natureza processual, e que colaborava com o avanço do conhecimento teórico, pois as pesquisas em LA além de operarem com conhecimento advindo de várias disciplinas, também formulavam seus próprios modelos teóricos, colaborando nâo somente no seu campo de açăo, como também em outras áreas de pesquisa.

A pesquisadora Vera Menezes em entrevista pela organizaçăo de um livro Conversas com linguistas aplicados - projeto esse que foi interrompido, define e sintetiza muito bem a abrangência da Linguística Aplicada

A LA trabalha além dos limites da frase, com unidades textuais ou discursivas, năo isola o sujeito da língua(gem) e olha com desconfiança para a objetividade e o distanciamento do pesquisador de seu objeto de estudo. Há um grande número de pesquisadores na LA que considera a objetividade como um construto problemático quando se lida com a complexidade da lingu(agem) na vida real e, por isso, valoriza a subjetividade, o contexto, a voz dos usuários. ${ }^{173}$

Como podemos perceber, a história da LA no Brasil é recente e embora as pesquisas estejam crescendo dentro das universidades e a LA tenha se firmado como uma área de estudos científicos reconhecida, ainda há poucas pesquisas no que se refere à sua terminologia, porque a LA é um campo em constante expansăo, sem delimitaçôes limítrofes e conceitos estanques, que se aproxima de outras áreas para compreender as práticas de linguagem presentes na sociedade, entendendo seus regimes de verdade, interpretando a relaçăo homem/língua, nas palavras de Moita Lopes (2006, p. 22), politizando "o ato de pesquisar e pensar alternativas para a vida social", dialogando com outras teorias buscando compreender "a multiplicidade de paradigmas que constituem o universo contemporâneo". Embora a inserçâo da LA nas academias brasileiras ainda pareça tímida e muitos estudiosos ainda nâo se intitulem linguistas aplicados, os

173 Disponível em: <www.veramenezes.com>. 
trabalhos relacionados ao entendimento e soluçăo dos problemas de linguagem proliferam nos programas de pós-graduaçăo e a necessidade do olhar crítico de linguistas aplicados nos mais diversos setores da sociedade se mostra cada dia mais evidente.

Dada a autonomia da LA como ciência e sua relevância nos estudos da linguagem, é importante que se sistematize as denominaçôes e conceitos manifestados na área, năo para prescrever usos, mas para facilitar o entendimento entre especialistas e a comunidade geral, para que a diversidade terminológica em LA năo se torne também um problema de linguagem. Por isso, acreditamos que estudos terminológicos podem contribuir para o fortalecimento da área e ajudar iniciantes e interessados nas questôes relativas à LA especialmente no que se refere às terminologias em uso para denominar a aprendizagem de línguas.

\section{PARADIGMA DA COMPLEXIDADE E QUESTÕES DE LÍNGUA}

Na seara dos Estudos Linguísticos, Larsen-Freeman e Cameron (2008) apontam como a Linguística vem reduzindo a complexidade da linguagem: descontextualizando -a, segregando-a e destemporalizando-a. A Linguística, assim, geralmente segue uma tradiçăo reducionista, analisando apenas as partes, os mecanismos, isoladamente, e nâo observando as dinâmicas e a nâo-linearidade dos sistemas linguísticos. Nessa mesma vertente, segue a Linguística Aplicada, por vezes lançando um olhar similar aos seus objetos de estudo, como, por exemplo, a aquisiçăo de línguas. Contrárias a essa vertente, as pesquisas conduzidas por linguistas aplicados, através da lente da complexidade, propóem investigaçōes mais holísticas.

Discorremos, inicialmente, sobre a Teoria do Pensamento Complexo - que informa o Paradigma da Complexidade em aspectos que interessam à reflexăo proposta. Posteriormente, explicamos como podemos compreender a língua como sistema adaptativo complexo e o papel da Terminologia para essa compreensáo.

\section{TEORIA DO PENSAMENTO COMPLEXO}

De acordo com Larsen-Freeman e Cameron (2008), muitas disciplinas săo progenitoras da teoria da complexidade, dentre elas estâo a Biologia com a teoria geral dos sistemas de von Bertalanffy (1975); a Matemática com as dinâmicas nâo-lineares de Poincaré; a Química com os sistemas dissipativos de Prigogine (2002); a Meteorologia de Lorenz (1963) com o efeito borboleta, entre outras. Todas elas contribuíram para o desenvolvimento do que se conhece por Paradigma da Complexidade ou Teoria do Pensamento Complexo, um campo científico novo, abrangente, sem definiçăo exata, mas que vem ganhando visibilidade e adeptos pelo fato de ser uma possibilidade teórica e metodológica de entender o "mundo fenomenal", palavras de Morin (2006, p.20).

Mesmo sendo, inicialmente, uma ciência da Física e da Matemática, a área da Educaçâo, inclusive a de Linguística Aplicada, passou a utilizar, nas últimas décadas, essa nova alternativa para a conduçâo de suas pesquisas: uma abordagem năo-reducionista e năo-linear, embasada no pensamento complexo (DAVIS; SUMARA, 2006).

O princípio do reducionismo, definido por Bertalanffy (1975) se refere à necessidade de que o conhecimento seja formulado em termos de cálculos e estatísticas para 
posterior validaçăo canônica. A abordagem năo-reducionista escapa de buscar situaçôes de causa e efeito e aceita o diálogo com outras disciplinas em situaçôes inter e pluridisciplinares.

A proposta do filósofo francês Morin, com ênfase na aprendizagem, retoma a ideia de que os saberes náo devem ser compartimentados, fechados dentro de áreas de conhecimento, mas sim, articulados entre si para que o ser humano possa ser compreendido em sua complexidade. "Todo conhecimento da realidade năo animado e controlado pelo paradigma da complexidade destina-se a ser mutilado" (MORIN, 1995). A aparente simplicidade da natureza é na verdade o resultado de interaçóes complexas entre inúmeros sistemas, entre os quais nós humanos estamos inseridos. Ao observarmos o mundo fenomênico, somos um sistema aninhado a outros sistemas, ou seja, sistemas que estăo incorporados e apresentam interconexóes.

Nessa mesma linha, a năo-linearidade "resulta das dinâmicas das interaçôes entre elementos e agentes" (LARSEN-FREEMAN; CAMERON, 2008, p. 30). Em um sistema complexo, que muda com o tempo, essas dinâmicas nâo sâo fixas e nem proporcionais aos insumos que recebe. No intuito de exemplificar o conceito, citamos Meara (2006) que demonstra que a aquisiçăo de vocabulário de uma língua adicional é năo-linear. Inicialmente, a aprendizagem começa vagarosamente; quando uma quantidade maior de palavras é aprendida, a aprendizagem se intensifica, mas volta a ficar lenta quando o estudante acredita que já conhece vocabulário suficiente.

Os sistemas complexos caracterizam-se, portanto, pela sua capacidade de autorregulaçăo, estabelecendo seus próprios parâmetros, e de autorreprodução, multiplicando-se dentro desses parâmetros estabelecidos. Assim como cada sistema é o produto de uma reaçăo inicial, da qual proliferará e expandirá cada organismo, que ao se desenvolver será o produtor de uma nova reaçăo que gerará outros organismos, de modo que o produto se transformará em produtor e, assim, sucessivamente. Cada elemento do sistema tem dentro de si as informaçóes de todo o sistema a que pertence, ou seja, a parte está dentro do todo, o todo, por sua vez, também está dentro da parte.

Leffa (2006) afirma que um bom exemplo desse sistema complexo é a relaçăo entre o indivíduo e a sociedade. Se, por um lado, cada indivíduo está dentro da sociedade, essa, por sua vez, encontra-se dentro de cada indivíduo. Nós, como indivíduos, participamos da sociedade por meio da língua que falamos; dos valores que pregamos; da cultura que possuímos. Tudo isso nâo nasceu de nós como geraçâo espontânea; foi colocada lá dentro pela sociedade. Em outras palavras, nós contemos a sociedade que nos contém.

Em suma, o que caracteriza os sistemas complexos é que seu comportamento emerge da interaçăo entre seus componentes. O comportamento emergente é năo-linear considerado desproporcional aos seus fatores causais. Os agentes ou elementos de um sistema complexo mudam e se adaptam em resposta a um feedback. Eles interagem de maneira estruturada com a interaçăo às vezes levando a uma organizaçăo própria e o surgimento de um novo comportamento (LARSEN-FREEMAN; CAMERON, 2008).

Em Hidden order, Holland (1995) apresenta sete características básicas dos sistemas adaptativos complexos, relacionadas com as propriedades informadas acima, sendo quatro propriedades e três mecanismos. Apresentamos essas características em forma de quadro (QUAD. 1) para melhor visualizaçăo. 
Quadro 1 - Características dos sistemas adaptativos complexos

\begin{tabular}{|c|c|c|}
\hline \multicolumn{2}{|r|}{ DENOMINAÇÃO } & EXPLICAÇÃO \\
\hline \multirow{4}{*}{ 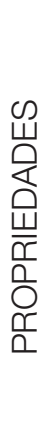 } & Agregação & $\begin{array}{c}\text { Forma padrão de simplificar sistemas complexos, agregando o que é similar em } \\
\text { categorias; relacionada à emergência de comportamento complexo em larga } \\
\text { escala pelas interações agregadas de agentes menos complexos. }\end{array}$ \\
\hline & Não-linearidade & $\begin{array}{c}\text { Propriedade das interações dos elementos em um sistema complexo que faz } \\
\text { com que o comportamento dos agregados seja mais complicado que a soma } \\
\text { das partes, sendo o produto desses agregados. }\end{array}$ \\
\hline & Fluxos & $\begin{array}{c}\text { Rede de nós e ligações; cadeia de mudanças que designa as interações } \\
\text { possíveis. }\end{array}$ \\
\hline & Diversidade & $\begin{array}{c}\text { Produto de adaptações progressivas; cada agente ocupa um nicho que é } \\
\text { definido pelas interações centradas naquele agente; se o agente é removido, há } \\
\text { uma cascata de adaptações, o que gera novidade perpétua. }\end{array}$ \\
\hline \multirow{3}{*}{ 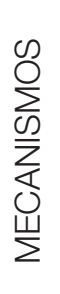 } & Marcas & $\begin{array}{c}\text { Embasam a organização hierárquica, delimitam as fronteiras nos sistemas } \\
\text { complexos e facilitam a formação de agregados. A marcação facilita a interação, } \\
\text { pois torna os agentes distinguíveis. }\end{array}$ \\
\hline & Modelos internos & $\begin{array}{l}\text { Usados para antecipação; os agentes selecionam padrões entre os insumos e } \\
\text { assim podem antecipar as consequências de suas escolhas. }\end{array}$ \\
\hline & Blocos constituintes & $\begin{array}{c}\text { Partes que compõem o sistema, que podem ser usadas e reusadas em uma } \\
\text { grande variedade de combinações. }\end{array}$ \\
\hline
\end{tabular}

Fonte: Adaptado de Holland, 1995. ${ }^{174}$

Larsen-Freeman e Cameron (2008) ilustram como o ecossistema de uma floresta é um sistema complexo. Seguindo Holland (1995), defendemos que os blocos constituintes podem ser agregados em agentes (animais, pássaros, insetos e até pessoas) e em elementos (árvores, ventos, chuva, solo, qualidade do ar, etc.). Essa agregaçăo é marcada pelos termos 'agentes' e 'elementos', que demonstram a diversidade, por serem de tipos distintos, por ocuparem seus nichos específicos. Esses agentes e elementos interagem em fluxos que mudam com o tempo e essa interaçăo leva à náo-linearidade, propriedade sobre a qual já discorremos que indica que as dinâmicas nâo săo fixas. A relaçăo entre os agentes e os elementos segue o mecanismo de modelos internos, por exemplo, o animal ao perceber o elemento chuva, pode utilizar-se do elemento árvore para se proteger, por prever que sua escolha pode significar que năo se molhará.

Na próxima subseçâo, retomamos as reflexóes postas para melhor compreensâo de língua e da Terminologia.

\section{COMPLEXIDADE, LÍNGUA E TERMINOLOGIA}

Como pesquisador da LA, Leffa (2006) destaca que nenhuma teoria possui todo o conhecimento necessário para explicar a aprendizagem de língua, a troca de informaçóes com outras teorias torna-se um pré-requisito básico no que se refere à investigaçăo da aprendizagem de uma LE. O referido autor afirma que,

um problema sério da área é a distância que existe entre o sujeito e o objeto a ser adquirido. A língua que falamos é a característica mais íntima da nossa identidade e está completamente entranhada em tudo o que somos, pensamos ou sentimos. Aprender a língua do outro é cometer uma violência contra a nossa pessoa nos domínios cognitivo, afetivo e psicomotor; temos que nos expor ao ridículo de

174 Essa e todas as demais traduçóes neste texto săo de nossa autoria. 
pronunciar sons que náo somos capazes de pronunciar, de aceitar valores que fomos ensinados a desprezar e a passar por idiotas na frente de falantes nativos por năo sermos capazes de compreender algumas frases da maneira como deveriam ser compreendidas. Nâo há como náo cometer gafes no processo de aprendizagem de uma língua estrangeira, quer seja rindo na hora errada, năo rindo na hora certa, dizendo ou deixando de dizer algo que deveria ou năo deveria ser dito numa determinada situaçăo (LEFFA, 2006, p. 30).

Para esse autor, o processo de aprendizagem de uma LE precisa de um sistema teórico dorsal, capaz de originar diferentes teorias. Esse sistema deve aceitar, tanto uma ênfase no indivíduo como na sociedade; no sujeito como no objeto, na forma como na funçâo e até mesmo os fundamentos de teorias contrárias uma da outra, como as estruturalistas versus as comunicativas.

Essa visâo de aprendizagem de línguas se embasa na compreensăo de língua como sistema complexo. "É importante sublinhar o fato de que năo há uma única língua padrâo para aprender. Ao invés disso, a língua existe como uma grande variedade de idioletos que dependem de diferentes gêneros, estilos de fala, classes sociais, etc." (KE; HOLLAND, 2006, p. 712). Isso significa que deve ser considerada a heterogeneidade de sistemas complexos, como a língua.

Segundo Beckner et. al. (2009, pp. 1-2),

Língua como sistema adaptativo complexo envolve as seguintes características centrais: o sistema consiste de múltiplos agentes (os falantes na comunidade de fala) que interagem um com ou outro. $\mathrm{O}$ sistema é adaptativo; ou seja, o comportamento dos falantes é embasado nas suas interaçóes passadas, e as interaçóes correntes e passadas juntas alimentam o comportamento futuro. O comportamento do falante é consequência de fatores que competem desde limitaçóes percebidas a motivaçôes sociais. A estrutura da língua emerge dos padróes inter-relacionados de experiência, interaçăo social, e mecanismos cognitivos.

Tomando novamente as características propostas por Holland (1995), explicitamos as propriedades e os mecanismos de uma língua, entendida como sistema adaptativo complexo.

Quadro 2 - Características de línguas como sistemas adaptativos complexos

\begin{tabular}{|c|c|c|}
\hline & DENOMINAÇÃO & EXPLICAÇÃO \\
\hline \multirow{4}{*}{ 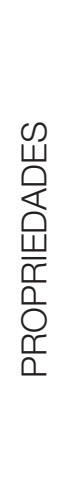 } & Agregação & $\begin{array}{c}\text { As interações entre os agentes em um contexto sócio-histórico-discursivo } \\
\text { específico fundamentam a emergência de uma língua. }\end{array}$ \\
\hline & Não-linearidade & $\begin{array}{c}\text { Uma língua não é a soma exata de todas as interações entre os falantes, pois a } \\
\text { soma das partes é maior ou menor do que o todo. Estruturas léxico-gramaticais, } \\
\text { atos de fala, contextos interativos, etc. conduzem à auto-organização e } \\
\text { emergência de sentido. Contudo nem todas emergências se estabilizam como } \\
\text { língua. }\end{array}$ \\
\hline & Fluxos & $\begin{array}{l}\text { Interações em um contexto geram outras interações em outros contextos em uma } \\
\text { rede de ligações. }\end{array}$ \\
\hline & Diversidade & $\begin{array}{c}\text { Uma língua é produto de adaptações progressivas; cada palavra, expressão, } \\
\text { sentença, etc. ocupa um nicho e se um elemento é removido, há uma cascata de } \\
\text { adaptações, o que gera novidade perpétua. }\end{array}$ \\
\hline
\end{tabular}




\begin{tabular}{|c|c|c|}
\hline \multirow{3}{*}{ 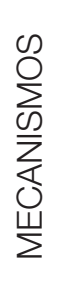 } & Marcas & $\begin{array}{l}\text { Sistemas complexos são marcados por termos, denominações que buscam } \\
\text { nomear as agregações. }\end{array}$ \\
\hline & Modelos internos & $\begin{array}{l}\text { Usados para antecipação; os agentes selecionam padrões entre os insumos } \\
\text { linguísticos e assim podem antecipar as consequências de suas escolhas. }\end{array}$ \\
\hline & Blocos constituintes & $\begin{array}{c}\text { Estruturas linguístico-discursivas são elementos do sistema linguísticos e falantes } \\
\text { são os agentes, os usuários desse sistema. Elementos e agentes são os blocos } \\
\text { constituintes. }\end{array}$ \\
\hline
\end{tabular}

Fonte: Holland (1995) traduzido por Souza (2011, p. 28).

Resumindo, entendemos que a língua é composta de padrōes emergentes estabilizados por seu uso. Essa estabilidade que encampa a variabilidade é marcada por termos que delimitam suas fronteiras tênues e será o foco da seçāo a seguir.

\section{TERMINOLOGIAS RELACIONADAS AO ENSINO DE LÍNGUAS NÃO MATERNAS: REFLEXÕES SOBRE CONCEITOS}

O espectro de temas que a LA engloba amplia-se cada vez mais. Segundo Grabe (2002), seu escopo de estudos inclui a aprendizagem e o ensino de L1, para além de seu foco inicial em contextos de LE. Por LM ou L1 entende-se a primeira língua que aprende um ser humano em sua infância e que normalmente chega a ser seu instrumento natural de pensamento e comunicaçăo. Com o mesmo sentido também se emprega língua nativa e, com menor frequência, língua natal. Quem compartilha uma LM é considerado falante nativo da língua em questăo. O termo "língua materna" costuma empregar-se em contraposiçấo à LE ou SL.

No intuito de tomar essa 'língua do outro', nâo como dicotomicamente oposta à nossa língua materna, mas imbricada em um contexto marcado pela pluralidade, recorremos ao Paradigma da Complexidade, que postula a ideia de que nada existe ou acontece de modo isolado no universo. Nada é tăo distante ou táo pequeno que nâo possa afetar tudo o que acontece ao nosso redor e dentro de nós.

Todas as sociedades, ocidentais ou orientais, que fazem uso oralizado e letrado de língua(gens) sâo unânimes em reconhecer o valor educacional, cultural, psicológico, prático e profissional de aprendizagem de uma nova(outra) língua. É possível observar esse reconhecimento, ainda mais valorizado, em países desenvolvidos em educaçăo e tecnologias, cujos processos de letramentos perpassam a inclusăo de disciplinas de ensino de LE em seus currículos obrigatórios. Muitas vezes, esses currículos contemplam mais de um idioma a ser aprendido. A necessidade e importância de aprendizagem de outros idiomas se torna mais evidente e crescente dados os fluxos de interaçóes propiciados pelas tecnologias atuais, pela facilidade de locomoçăo entre os países, pelo acesso a grandes bancos de dados do mundo todo, devido às trocas comerciais, entre outras açóes transnacionais. Tudo isso coloca em perspectiva os conceitos e terminologias criados para expressar os processos envolvendo línguas em aprendizagem e suas funçōes em um dado contexto, que hoje mostra-se diverso, heterogêneo, pluriforme, multimodal, complexo.

Nesse sentido, observamos uma multiplicidade de termos para referirmo-nos às línguas nâo-maternas, ora dizendo respeito ao seu processo de aquisiçăo e aprendizagem, 
ora à funçăo social ou contextual em que se fazem presentes. Para exemplificar, tomamos Friedrich e Matsuda (2010), que fazendo referência ao inglês, atestam que há diferença conceitual entre o processo de aprender e a funçâo que uma língua exerce socialmente e isso deve ser marcado por termos que expressem essas relaçóes. Eles acreditam que o termo língua franca (LF) descreve uma funçâo que o inglês apresenta em contextos multilíngues e que inglês como língua internacional (LI) refere-se a casos especializados em que a língua inglesa é usada em contextos internacionais. Ao invés de uma variedade, o termo língua franca expressa uma funçăo que capta a complexidade e diversidade do inglês hoje no mundo. A língua franca é uma língua que é adotada como língua comum entre os falantes cujas línguas nativas sâo diferentes. Friedrich e Matsuda (2010) complementam que na sociedade contemporânea, o termo língua franca foi expandido para incluir năo só as situaçōes de língua de contato em estruturas sociais abertamente desiguais, mas também qualquer situaçăo em que uma língua comum, incluindo uma língua transplantada, é usada por falantes de diferentes origens linguísticas em uma determinada comunidade, domínio ou foco. Os mesmos autores citados afirmam que

[A] língua franca é, por definiçăo aprendida como SL por pelo menos por alguns de seus falantes, mas os pesquisadores também reconhecem que algumas línguas francas săo também aprendidas como L1 por alguns falantes. (FRIEDRICH; MATSUDA, 2010, p. 21)

O uso de LF é uma das muitas funçōes que o Inglês desempenha na sociedade de hoje, e tal uso evidencia a complexidade de um mundo em que as relaçôes comerciais e os fluxos de pessoas tomaram proporçôes globais, como jamais visto. E nâo há linearidade entre as funçôes e a forma como as línguas sâo adquiridas, o que demonstra a complexidade da linguagem.

Diante dos cenários atuais que têm exigido terminologias condizentes com a complexidade de fatores que se encontram presentes nas interaçōes linguísticas comunicacionais e que possam fazer justiça à multiplicidade de línguas que, hoje, as sociedades em desenvolvimento estăo em constante contato, observamos também uma multiplicidade de termos para referirmo-nos às línguas náo-maternas. Tomemos três desses termos para mais uma exemplificaçăo:

Língua de herança: Contexto em que a língua e a cultura de crianças e adolescentes filhos de pais imigrantes săo ensinados com o objetivo de fortalecimento cultural, melhoria de autoestima ou de preservaçăo do patrimônio cultural desses jovens e riqueza cultural do país de acolhimento. (GLOSSÁRIO, 2013).

Língua-alvo: A língua estrangeira, segunda ou mesmo a materna em que o aprendiz se esforça para aprender, adquirir ou aperfeiçoar. Língua para ser desenvolvida por aprendizagem ou aquisiçăo. (GLOSSÁRIO, 2013).

Língua de acolhimento: Idioma majoritário do país anfitriâo de estudantes imigrados ou refugiados. É ensinado nas escolas como segunda língua. (GLOSSÁRIO, 2013).

Observamos que por mais que os três termos sejam utilizados em oposiçấo à LM ou L1, cada definiçáo apresenta sua especificidade.

Nesses três exemplos, o conceito e sua correspondente terminologia estăo ligados 
cada um a um processo específico, que acreditamos, nem sempre em oposiçăo à LM. No primeiro caso, a preservaçáo do patrimônio cultural linguístico herdado dos progenitores, e assim, a língua dos pais pode ser aprendida em concomitância com a língua majoritariamente falada no país de nascimento da criança. Mas essa língua dos pais năo seria também uma língua materna, visto que a definiçăo de LM diz respeito à língua aprendida em casa (KELLOG, 2009)? No caso da língua-alvo, é uma terminologia que denomina o conceito ligado ao processo de aprendizagem de uma língua qualquer que se queira ou necessite aprender, ela é alvo, objeto de aprendizagem, formal ou natural. De acordo com essa definiçăo, a língua-alvo năo se opóe à L1, esta poderia ser um subsistema da língua-alvo. No terceiro exemplo, uma língua de acolhimento poderia ser uma segunda língua e, com o passar do tempo, essa língua poderia tornar-se a única língua de expressăo desse indivíduo, caso ele năo tenha mais contato com sua língua de origem. Nesse caso, essa língua tornar-se-ia o que?

A dificuldade em encontrar uma denominaçăo mais ampla se dá em relaçăo às peculiaridades de situaçōes linguísticas que podemos constatar, tais como em países monolíngues, bilíngues, multilíngues ou com línguas de imigraçăo. No Brasil, assim como em diversos outros países, há outras línguas năo-oficiais faladas no dia-a-dia por grupos de pessoas de determinadas comunidades. É compreensível, portanto, que o status de uma língua específica pode ocasionalmente se alterar dependendo do uso que se faz da língua, ou seja, uma língua estrangeira pode se tornar, com o tempo, uma língua materna ou uma SL.

Um fenômeno observável e crescente nos dias atuais, em naçóes em desenvolvimento, é a internacionalizaçâo de seus idiomas, que passam ao status de LE e/ou SL e/ ou língua adicional e/ou língua năo materna, como queiram assim denominar. Como linguistas aplicados, confrontamo-nos habitualmente com dois conceitos de utilizaçâo recorrente - SL e LE - muitas vezes sem nos atentarmos a quáo peculiares sáo esses termos e quăo específicas săo suas definiçōes.

A terminologia SL năo representa necessariamente uma questăo de ordem, no sentido de que poderá haver uma terceira, quarta, ou outras na sequência. 0 termo "Segunda" faz referência a uma "outra" língua que nâo foi a primeira, que no caso é chamada de LM ou L1. A ordem de aquisiçâo nâo é relevante desde que nâo haja mais de uma L1. Dependendo de como a língua é adquirida altera-se a forma de classificá-la.

Pupp Spinassé (2006) afirma que, diferentemente do conceito de LE,

uma SLé uma năo-primeira-língua que é adquirida sob a necessidade de comunicaçăo e dentro de um processo de socializaçấo. A situaçâo tem que ser favorável: um novo meio, um contato mais intensivo com uma nova língua que seja importante para a comunicaçấo e para a integraçáo social. Para o domínio de uma SL é exigido que a comunicaçáo seja diária e que a língua desempenhe um papel na integraçăo em sociedade. (PUPP SPINASSÉ, 2006, p. 06)

Entende-se por LE uma língua que pode ser aprendida ou adquirida em espaços remotos em relaçấo ao lugar onde é falada como LM e inclui o uso de recursos metodológicos, sobretudo, quando se tratar de ensino formal. Distintamente da SL ou LM, que săo línguas pátrias faladas em um contexto político-social, a LE pode ser apenas um instrumento linguístico, nâo menos importante, que serve, de forma pontual, para dar acesso à literatura, ao turismo e à cultura. Ainda, a LE pode ser uma disciplina de 
programas curriculares educacionais, que abrangem alunos de níveis de ensino básico ou médio, como é o caso no Brasil, do Inglês, do Espanhol e/ou outras línguas, ou mesmo ser ensinada em institutos especializados no ensino de idiomas.

Ao fazermos uma análise sobre a terminologia SL e LE, e focarmos em fatores como "nível de proficiência" ou "objetivos de aprendizagem", encontraremos dificuldades em determinar qual terminologia empregar porque a SL pode ser considerada uma LE, dependendo em que fase se encontra a aprendizagem. Do ponto de vista cognitivo, as diferenças na aprendizagem de uma SL ou LE podem ser evidentes na medida em que o objetivo de aprendizagem se distinguir. Na verdade, o nível de proficiência em SL pode ser mais abrangente do que em LE, no sentido de que em SL o sujeito necessitará atingir altos níveis de proficiência para poder compreender bem os enunciados, escritos ou orais, ou seja, com elevado grau de complexidade para as diferentes situaçôes que assim exijam.

Na aprendizagem de LE, o sujeito poderá ser confrontado com situaçóes pontuais de necessidade imediata de compreensâo e de locuçâo em termos mais complexos de uma determinada Língua, mas nâo de forma frequente, como no caso da utilizaçâo de SL. Considerando este último contexto, o esforço na tarefa de aprendizagem e a acomodaçăo das "estruturas" mentais do estudante face à informaçăo que o novo código implica, supóe, assim, desenvolvimento de mecanismos de controle que podem se perpetuar.

Outra significativa diferença é que a LE pode nâo servir à situaçâo de comunicaçăo entre os falantes e, a partir disso, năo ser fundamental para a integraçáo social do sujeito, enquanto que a SL pode desempenhar um papel vital na sociedade em que um falante se insere.

Ellis (1994) defende o ponto de vista de que a diferenciaçăo entre os dois termos năo deve estar em fatores psicolinguísticos, mas sim nos sociolinguísticos. De acordo com esse autor, o processo de aquisiçăo de uma SL ocorre quando "a linguagem desempenha um papel institucional e social na comunidade", enquanto que a aquisiçăo de uma LE ocorre, especialmente, "em locais onde a linguagem năo desempenha um papel tâo importante na comunidade sendo, primeiramente, aprendida apenas nas salas de aula". (ELLIS, 1994, p. 12)

Observamos que o contexto de SL favorece maior competência e melhor desempenho, pois o meio ou a situaçâo imediata em que o falante estiver inserido vai exigir isso, contrariamente, o aprendiz de LE năo especificamente vai precisar chegar ao mesmo nível de conhecimento de um falante de SL.

Ainda em relaçăo ao contraste entre SL e LE, Stern (1983) afirma que há certo consenso de que o termo SL deva ser aplicado para especificar a aprendizagem e o uso de uma língua năo-nativa dentro de fronteiras territoriais em que ela tenha uma funçâo reconhecida, enquanto o termo LE deve ser empregado para definir a aprendizagem e o uso em contextos, os quais essa LE nâo tenha qualquer status sociopolítico.

A SL é reconhecida, normalmente, como a ou uma das línguas oficiais de um país por ser essencial para a participaçâo dos sujeitos na vida política e econômica. Dessa forma, há muitos inputs que favorecem a aprendizagem năo sendo necessária aprendizagem formal escolarizada. 
Podemos concluir que năo há uma regra específica que diferencie SL de LE, pois a situaçăo de aquisiçăo de uma língua e o seu nível de proficiência pode se alterar com o tempo, tornando necessário apenas estabelecer outra relaçăo com ela. Por exemplo, se um sujeito aprende o inglês como SL na Inglaterra, muda para o Brasil, essa língua anglo-saxônica perde a importância em sua vida diária, o sujeito pode deixar de lado essa relaçăo básica com a língua inglesa que pode se tornar, com o passar do tempo, uma LE ou, até mesmo, ser totalmente esquecida. Da mesma forma, qualquer língua que antes fora uma LM ou L1, poderá sofrer o mesmo fenômeno. Portanto, a distinçâo năo é absoluta, cada caso deve ser avaliado diante de cada especificidade sociolinguística e náo apenas sob a perspectiva psicolinguística como fora feito pela Linguística, anteriormente.

Hall, Smith e Wickasono (2011) propóem que no lugar de SL e LE seja utilizado o termo língua adicional. Os autores pontuam que esses conceitos envolvem nâo apenas questôes de convençăo acadêmica e de embasamento teórico, mas também de contexto sociopolítico.

Língua adicional é, também, o termo preferido em relaçăo à LE de acordo com a $\mathrm{ALAB}^{175}$. Essa nova terminologia se faz importante porque considera, além do que é aprender língua estrangeira, a língua que desejamos e, principalmente, a quem estamos servindo ao aprendermos determinadas línguas. Essa nomenclatura está sendo adotada no Canadá há alguns anos em relaçáo ao ensino de inglês - em substituiçáo aos termos; "Inglês Segunda Língua" ou "Língua Estrangeira", que săo as nomenclaturas tradicionais. Vários outros países têm seguido essa mesma tendência. Os Estados Unidos criaram sua própria nomenclatura: "Língua Nova" - English as a New Language.

No Brasil, é possível encontrar artigos acadêmicos que se referem ao ensino de língua inglesa como língua adicional. Rottava (2009), por exemplo, discorre sobre a pertinência do termo para pesquisas envolvendo contextos bilíngues e trilíngues. Essa tendência tem encontrado respaldo na percepçâo de que muitos países, como a Índia, a Suíça e vários outros da África e do Oriente Médio, săo culturas multilíngues, que contrastam claramente com os demais países ocidentais, que em sua maioria, săo monolíngues ou, no máximo, bilíngues como o Canadá, por exemplo.

Schlatter e Garcez (2009) pontuam que ao utilizarmos 'língua adicional', apagamos a diferenciaçăo dicotômica entre falantes nativos e năo-nativos, entre primeira e segunda língua. Como defendemos ao longo deste texto, essas diferenças náo se sustentam como polarizadas, especialmente no contexto atual, marcado por fronteiras tênues e por tecnologias digitais que permitem, segundo Demo (2002), ligaçóes virtuais efetivas e mesmo afetivas, o que nâo é determinado por distintas territorialidades ou naçóes.

Falar de uma língua adicional em vez de uma língua estrangeira enfatiza o convite para que educandos (e educadores) usem essas formas de expressăo para participar na sua própria sociedade; esse convite envolve também a reflexăo sobre que língua é essa, de quem ela é e de quem pode ser, a que ela serve, o que cada um tem a ver com ela (SCHLATTER; GARCEZ, 2009, p. 127).

175 Disponível em: <http://www.alab.org.br/pt/noticias/outras-noticias/126-politica-educacional-linguistica-emconstrucao>. 
Compreendendo que "a complexidade é efetivamente o tecido de acontecimentos, açôes, interaçôes, retroaçōes, determinaçōes, acasos, que constituem nosso mundo fenomênico" (MORIN, 2006, p. 13), a defesa de Schlatter e Garcez (2009) se encaixa no que postulamos como um complexo de elementos em interaçâo. A língua adicional emerge da tessitura dos elementos do contexto no qual ela é utilizada e por isso năo pode ser vista como estática, e sim em constante ressignificaçăo.

Pensamos nos termos que designam a língua aprendida, assim como a aprendizagem em si, como um sistema adaptativo complexo, porque acreditamos que os conceitos que os termos veiculam năo săo estanques e lineares, e sim um sistema dinâmico, aberto e nâo-linear.

Paiva (2006, p. 91) relembra que

um sistema complexo náo é um estado, mas um processo. Cada componente do sistema pertence a um ambiente construído pela interaçăo entre suas partes. Nada é fixo, ao contrário, existe um constante movimento de açăo e reaçăo e mudanças acontecem com o passar do tempo.

A língua que é em um momento aprendida como estrangeira pode tornar-se segunda língua, uma língua adicional, ou até uma língua ad hoc, ou seja, ser aprendida e esquecida dado o contexto e necessidade que motiva a aprendizagem.

Os recentes processos de globalizaçăo, que permitem a movimentaçáo de pessoas entre fronteiras, em larga escala, evidenciam ainda mais esse contraste. Para muitos falantes, o inglês, o espanhol, o português entre outros, seria apenas mais uma língua em seu repertório linguístico, ou seja, uma língua adicional. Em tempos de internet, os fluxos linguísticos intensificados pelas tecnologias de interaçâo e comunicaçáo, evidenciaram as relaçōes dinâmicas em que os sistemas humanos se estruturam e essa percepçăo do todo, das relaçôes que se imbricam parece fazer mais sentido.

O termo língua adicional parece ser mais apropriado nos tempos atuais, porque além de ser mais abrangente parece contemplar tanto a aprendizagem das quatro habilidades clássicas, como o letramento crítico e a autonomia de línguas como o inglês que se apresenta como uma língua franca que deve estar a serviço da cultura local.

Ao se falar em língua adicional estamos pensando em um conjunto de línguas que estâo presentes no mundo globalizado e que gozam de importância para a comunicaçăo e interaçăo tanto global quanto local, como o espanhol, francês, português materno ou adicional e línguas minoritárias, entre outras, que nâo estăo em oposiçăo, mas em sinergia de forças que interagem para a formaçăo do todo que é o conhecimento dos interagentes.

Ao nos referirmos aos termos que expressam as relaçóes descritas, observarmos que os dados terminológicos em seu ambiente natural no discurso, sofrem variaçōes de acordo com os diferentes registos funcionais nas comunicaçôes especializadas. De acordo com Cabré (2003) os dados terminológicos em contextos naturais săo menos sistemáticos, menos inequívocos, menos universais do que previam os teóricos da teoria clássica da Terminologia. A razâo para isso é óbvia: em escrita e falada especializada os termos de discurso sâo um meio de expressăo e comunicaçăo e de acordo com essas duas variáveis o discurso será marcado pela redundância conceitual e variaçâo sinonímica e, além disso, permitem a observaçăo de que năo há sempre uma equivalência 
perfeita entre as línguas. Assim como a língua geral, a linguagem de especialidade é um conjunto de interaçôes negociadas, reconhecidas pela marcaçâo dada ao discurso, que sâo as unidades lexicais ou elementos gráficos que constituem os termos. O conhecimento especializado dessas marcaçóes se constrói no contexto temático e situacional de cada designaçăo e ele é consolidado por meio da compilaçăo de glossários que ajudam a entender a unidade especializada e seus usos.

Segundo Cabré (2003) a construçáo de uma teoria que descreve adequadamente e explica os termos pressupóe que a terminologia em geral, e, portanto, suas unidades, é multidimensional. Mas para entender um termo é preciso selecionar um ponto de acesso, uma "porta" ou inscriçấo que seja suficientemente ampla para respeitar a multidimensionalidade do objeto para documentar em detalhes descritivos ou explicativos a denominaçăo que se quer analisar. A autora supracitada afirma que descrever adequadamente as unidades terminológicas, suas características e propriedades, as relaçōes entre os seus componentes intrínsecos, suas funçōes, as relaçōes que estabelecem entre si e com outras unidades de conhecimento especializado e os processos da língua geral é, sem dúvida, uma tarefa que requer as contribuiçôes de muitos pesquisadores em um esforço cooperativo para a criaçăo de um modelo teórico mais apropriado a realidade multifacetada e complexa em que nos encontramos.

\section{CONSIDERAÇÕES FINAIS}

Propusemo-nos a refletir sobre a multiplicidade de terminologias que estăo sendo utilizadas pela LA no que se refere ao ensino e aprendizagem de línguas que năo LM ou L1. Em virtude de esses termos se mostrarem dinâmicos, complexos, năo lineares e estarem se expandindo diante da diversidade linguística que vivenciamos, atualmente, vimos a necessidade de uma abordagem mais crítica dos mesmos, em relaçâo aos contextos em que se apresentam ou têm sido empregados.

Procuramos chamar a atençăo de pesquisadores que se interessam pela área para atentarem para a diversidade de termos que designam línguas em aprendizagem e que carecem de reflexăo crítica em virtude do momento histórico que vivemos, permeado por tecnologias digitais de informaçâo e comunicaçâo e por abordagens teóricas que permitem uma visăo complexa do tempo e do espaço, e que se aplicam ao ensino e à aprendizagem de línguas.

Diante do que foi apresentado nesse artigo propomos que a terminologia 'língua adicional' seja utilizada, por nós profissionais do ensino de línguas, por parecer ser mais condizente com o caráter (in)disciplinar adotado pela LA, pois parece abranger a complexidade envolvida nos sistemas linguísticos e na aprendizagem e aquisiçáo de línguas "outras", ou seja, adicionais.

Aprendemos que a Terminologia como área do conhecimento linguístico que tem como tarefa dar tratamento descritivo às línguas de especialidade e dar conta da complexidade das unidades terminológicas, permitindo ir além dos aspectos linguísticos, no sentido de otimizar a comunicaçăo científica e tecnológica, pode aliar-se à LA e prestar um serviço à sociedade viabilizando e difundindo a comunicaçâo especializada por meio da confecçăo de dicionários, glossários, enciclopédias, vocabulários, banco de 
dados, entre outras aplicaçóes que visam à transferência de informaçóes especializadas. Devido a esse caráter pragmático da Terminologia percebemos sua tangência com a LA. O próprio Wüster, além de incluir a Linguística como matéria interdisciplinar à Terminologia, considerou-a como um ramo da Linguística Aplicada. Por isso, acreditamos que é papel da LA preocupar-se com questōes terminológicas e inserir em sua agenda de investigaçóes a Terminologia.

Ao olhar para o termo 'língua adicional' através das lentes do Paradigma da Complexidade, percebemos que ao invés de dicotômicos, termos como língua primeira, segunda e terceira podem estar mais imbricados do que imaginávamos devido à pluralidade de contextos em que essa 'língua adicional' pode emergir. Para além de considerarmos lados distintos da mesma moeda, uma figura mais apropriada para pensarmos no que propomos seja um prisma ou um caleidoscópio, apresentando uma unidade repleta de movimento que parece capturar dinamicidade e heterogeneidade. 


\section{REFERÊNCIAS}

ALMEIDA FILHO, J. C. P.; SCHMIDT, J. R. Glossário de Linguística Aplicada. Campinas: Pontes, 1998.

BERTALANFFY, L. Teoria geral dos sistemas. 2 ed. Traduçăo Francisco M. Guimarăes. Petrópolis: Vozes, 1975. 351 p.

CABRE, M. T. La terminología: representación y comunicación - elementos para una teoría de base comunicativa y outros artículos. Barcelona: Institut Universitari de Linguística Aplicada, 1999.

La terminología: teoria, metodologia e aplicaciones. Barcelona : Editorial Antártida/Empúries, 1993.

Theories of terminology Their description, prescription and explanation. Terminology 9:2, 163-199, 2003. Disponível em: <http://www.upf.edu/pdi/dtf/teresa. cabre/docums/ca03tgy.pdf>. Acesso em: 25 nov. 2013.

CANO, W. M. Teoria e práxis de um dicionário escolar de ciências. Tese de Doutorado. Araraquara: UNESP, 2001.

DAVIES, A. A Glossary of Applied Linguistics. New Jersey: Lawrence Erlbaum Associates, 2005.

DAVIS, W. What is applied linguistics. Disponível em: 〈www.cambried.org/elt>. Acesso em: 25 nov. 2013.

DAVIES, Alan; ELDER, Catherine. Applied Linguistics: Subject to discipline?.The handbook of applied linguistics, pp. 1-15, 2004.

ELLIS, R. The study of Second Language Acquisition. Oxford: Oxford University Press, $1994.825 \mathrm{p}$.

FRIEDRICH, P. ; MATSUDA, A. When five words are not enough: a conceptual and terminological discussion of english as a lingua franca. International Multilingual Research Journal, n.4, pp. 20-30, 2010.

GLOSSÁRIO de linguística aplicada. Disponível em: 〈http://glossario.sala.org.br/〉. Acesso em: 19 nov. 2013.

GRABE, W. Applied Linguistics: an emerging discipline for the twentieth century. In: KAPAN, Robert B. (Ed.). The Oxford Handbook of Applied Linguistics. Oxford: Oxford University Press, pp. 3-12, 2002.

HALL, C. J.; SMITH, P. H.; WICKASONO, R. Mapping Applied Linguistics: a guide for students and practitioners. New York: Routledge, 2011.

HOLLAND, J. Hidden order: how adaptation builds complexity. Reading, MA: Addison Wesley, 1995. 185 p.

HOUSE, J. What is applied linguistics. Disponível em: 〈www.cambried.org/elt>. Acesso em: 25 nov. 2013. 
JOHNSON, K.; JOHNSON, H. (Ed.). Encyclopedic Dictionary of Applied Linguistics: a handbook for language teaching. Oxford: Blackwell, 1998.

KE, J.; HOLLAND, J. H. Language origin from an emergentist perspective. Applied Linguistics, Oxford: Oxford Journals, v. 27, n. 4, pp. 691-716, 2006.

KELLOG, M. WordReference.com: Online language dictionaries. Retrieved January, v. $12,2009$.

LARSEN-FREEMAN, D. Chaos/complexity science and second language acquisition. Applied Linguistics, v. 2, n. 18, 1997, pp.141-165.

LARSEN-FREEMAN, D.; CAMERON, L. Complex systems and applied linguistics. Oxford: Oxford University Press, 2008.

LEFFA, V. J.. Transdisciplinaridade no ensino de línguas: a perspectiva das Teorias da Complexidade. Rev. bras. linguist. apl. [online]. 2006, vol.6, n.1, pp. 27-49. Disponível em: <http://dx.doi.org/10.1590/S1984-63982006000100003〉.

LORENZ, E. N. Deterministic nonperiodic flow. Journal of the Atmospheric Sciences, v. 20, n. 2, pp. 130-141, march 1963.

MEARA, P. Emergent properties of multilingual lexicon. Applied Linguistics, Oxford: Oxford Journals, v. 27, n. 4, pp. 620-644, 2006.

MENEZES, V.; SILVA, M. M.; GOMES, I.F. Sessenta anos de Linguística Aplicada: de onde viemos e para onde vamos. In: PEREIRA, R.C.; ROCA, P. Linguística aplicada: um caminho com diferentes acessos. Sâo Paulo: Contexto, 2009.

MOITA LOPES, L. P. Afinal, o que é Linguística Aplicada? In: MOITA LOPES, L.P. Oficina de Linguística Aplicada. Campinas: Mercado de Letras, p.17-26, 1996.

.Uma Linguística Aplicada mestiça e ideológica: interrogando o campo como linguista aplicado. In: MOITA LOPES, L.P. (Org.). Por uma Linguística Aplicada Indisciplinar. Sáo Paulo: Parábola Editorial, 2006, p. 13-44.

MORIN, E. Terra-Pátria. Porto Alegre: Sulina, 1995. 2006.

Introduçăo ao pensamento complexo. Traduçăo Eliane Lisboa. Porto Alegre: Sulina,

PAIVA, V. L. M. O. Caleidoscópio: fractais de uma oficina de ensino aprendizagem de língua inglesa (Memorial p/ concurso de Prof. Titular). Belo Horizonte: Faculdade de Letras da UFMG, 2002.

. Autonomia e Complexidade. Linguagem e Ensino, Pelotas, v. 9, n. 1, p. 77-127, 2006.

PENNYCOOK, A. A Lingüística Aplicada Dos Anos 90: Em Defesa De Uma Abordagem Crítica. In: SIGNORINI, I. \& CAVALCANTI, M. (Orgs.). Linguística Aplicada e transdisciplinaridade: questôes e perspectivas. Campinas: Mercado de Letras, 1998. p.23-47.

PRIGOGINE, I. As leis do caos. Traduçâo Roberto Leal Ferreira. Săo Paulo: Editora Unesp, 2002.

PUPP SPINASSÉ, K. Os conceitos Língua Materna, Segunda Língua e Língua Estrangeira e os falantes de línguas alóctones minoritárias no Sul do Brasil. Revista Contingentia, UFRGS, v. 1, p. 01-10, nov. 2006. 
ROJO, R. H. R. Perspectivas para os estudos sobre a linguagem na Virada do Milênio: o caso da Linguística Aplicada. Mesa Redonda. V Seminário de Teses em Andamento. UNICAMP: IEL, 28 out. 1999. 1999.

ROTTAVA, L. Português como língua terceira (L3) ou língua estrangeira (LE) adicional: a voz do aprendiz indicando identidade. Em aberto, Brasília, v. 22, n. 81, p. 81-98, 2009.

SCHLATTER, M.; GARCEZ, P. M. Línguas Adicionais. In: RIO GRANDE DO SUL, Secretaria do Estado da Educaçăo, Departamento Pedagógico. Referenciais curriculares do Estado do Rio Grande do Sul: linguagens, códigos e suas tecnologias. Porto Alegre: SE/DP, 2009. P. 127-172.

SOUZA, V. V. S. Dinamicidade e adaptabilidade em comunidades virtuais de aprendizagem: uma textografia à luz do paradigma da complexidade. 2011. Tese de Doutorado. Programa de Pós-Graduaçăo em Estudos Linguísticos, Faculdade de Letras, Universidade Federal de Minas Gerais. Belo Horizonte, 2011.

STERN, H. Fundamental Concepts of Language Teaching. Oxford: Oxford University Press, 1983. 